\title{
Rapid Adhesion and Spread of Non-adherent Colon Cancer Colo201 Cells Induced by the Protein Kinase Inhibitors, K252a and KT5720 and Suppression of the Adhesion by the Immunosuppressants FK506 and Cyclosporin A
}

\author{
Takashi Mohri*, ${ }^{*}$, Isamu Kameshita**, Shintaro Suzuki ${ }^{\dagger \dagger}$, Koshiro Hioki*, Rikio Tokunaga ${ }^{\dagger}$ and \\ Shigeru Takatani ${ }^{\dagger, 1}$ \\ Second Department of Surgery* and Department of Hygiene ${ }^{\dagger}$, Kansai Medical University, Moriguchi, Osaka \\ 570-8506, Japan, **Department of Biochemistry, Asahikawa Medical School, Asahikawa, Hokkaido 078-8311, \\ Japan and ${ }^{\dagger \dagger}$ Institute for Developmental Research, Aichi Human Service Center, Kasugai, Aichi 480-0304, \\ Japan
}

Key words: colon cancer cells/cell adhesion/cell spreading/K252a/KT5720 and FK506

\begin{abstract}
$A B S T R A C T$. We examined alterations in cell morphology and expression of adhesion molecules in response to a general protein kinase inhibitor K252a treatment of non-adherent colon adenocarcinoma Colo201 cells. K252a induced rapid cell adhesion and spreading with concomitant formation of actin stress fibers. A protein kinase A inhibitor KT5720 also induced cell adhesion, but the rate of spread was slower than that seen with K252a. These adhesions were mediated by integrin molecules since cell adhesion required $\mathrm{Mg}^{2+}, \mathrm{Mn}^{2+} \mathrm{or}^{2}$ $\mathrm{Ca}^{2+}$, and was inhibited by monoclonal antibodies for integrins $\alpha_{2}$ and $\beta_{1}$. Indirect immunofluorescence microscopic observations revealed that integrin $\alpha_{2}$ and $\beta_{1}$ molecules in $\mathrm{K} 252 \mathrm{a}$-treated cells were concentrated at sites of focal adhesion, but expressions of integrin molecules were not modulated. Tyrosine phosphorylation of focal adhesion kinase (FAK) and paxillin increased during K252a- or KT5720-induced cell adhesion. Immunosuppressants FK506 and cyclosporin A suppressed the K252a-induced cell adhesion and abolished tyrosine phosphorylation of cellular proteins including FAK and paxillin. Furthermore, W7 and calmidazolium, inhibitors of calmodulin, also inhibited the cell adhesion. Based on findings that FK506 and cyclosporin A are inhibitors of the calcium calmodulin-dependent protein phosphatase, calcineurin, this phosphatase may regulate integrin-dependent cell adhesion and spread of Colo201 cells. This Colo201 cell model provides a pertinent system for studying molecules involved in signal transduction pathways and can shed light on mechanisms of metastasis and invasion of colon carcinoma cells.
\end{abstract}

Cell adhesion to extracellular matrix (ECM) is involved in diverse cellular processes, including cell migration and differentiation $(10,17)$. Cells in culture adhere to ECM components at discrete contact sites termed focal adhesion where integrins bind to ECM and a large number of cytoplasmic proteins, some of which are likely to play a role in intracellular responses of extracellular signals. The formation of focal adhesion involves members of the rho family of GTP-binding proteins (23) and increased tyrosine phosphorylation of several focal adhesion-associated proteins such as focal adhesion kinase (FAK), paxillin, and tensin $(1,12)$. Tyrosine phosphorylation of and recruitment of focal adhesion is an early event in the adhesion-induced signal-

1 To whom correspondence should be addressed.

Tel: +81-6-993-9436, Fax: +81-6-992-3522

E-mail: taketani@takii.kmu.ac.jp ing pathway (7), and it has been shown that the level of tyrosine phosphorylation of FAK correlated with assembly of focal adhesion and actin stress fibers (4). The mechanisms of signal transduction in each system is becoming clear, but very little is known about molecules responsible for invasion and metastasis of human colon cancer.

Several integrins can bind their ligands if they are activated in response to physiological and non-physiological stimulation. This process is known as 'inside-out' integrin signalling (11). Several observations suggest that there are cytoplasmic signalling pathways that regulate integrin activation (11). For example, cell migration requires co-ordinated adhesion and deadhesion events, and platelet-derived growth factor inhibits platelet activation, thereby suggesting that activation of tyrosine kinase receptors impairs the function of integrin $\alpha_{\mathrm{IIb}} \beta_{3}(6,22)$. Treatment of mouse 3T3 cells with 
mitogens, including platelet-derived growth factor, lysophosphatidic acid and sphingosylphosphoryl choline resulted in increases in tyrosine phosphorylation of FAK and paxillin followed by profound alterations in organization of actin fibers and in the assembly of focal adhesion $(25,33,34)$. Furthermore, 12- $O$-tetradecanoylphorbol-13-acetate (TPA) exerts profound effects on cells through activation of protein kinase $\mathrm{C}$ induced cell adhesion of leukemia cells to marrow stromal cells via integrin $\alpha_{5} \beta_{1}$ (19). TPA also caused spreading of colon cancer SW1116 cells (29). On the other hand, an increase in cAMP and activation of protein kinase $\mathrm{A}$ have been reported to induce the disassembly of stress fibers in a variety of cell types $(5,35)$. Thus, tyrosine kinases and serine/threonine kinases play critical roles in signal transduction through integrins.

Immunosuppressants cyclosporin A and FK506 bind to intracellular immunophilin, cyclophilin and FK506binding protein (FKBP), respectively (18). These complexes specifically bind to and inhibit the phosphatase activity of calcineurin. The migration of neutrophils on vitronectin was also inhibited by FK506 (8). Furthermore, association of integrin $\alpha_{5} \beta_{1}$ with fibronectin with Chinese hamster ovary cell lysates in vitro is regulated by the calcium-dependent phosphatase activity of calcineurin (24). Thus, calcineurin activity may regulate cellECM interaction either directly by regulating phosphorylation of integrins or integrin-associated proteins, or indirectly by initiating a cascade of other phosphoserine/threonine or phosphotyrosine phosphatases and kinases (8).

Colo201 cells isolated from ascites of a patient with adenocarcinoma of the colon is a unique cell line in that it has lost its epithelial appearance and has a nonadherent morphology (32). To clarify mechanisms involved in cell adhesion and metastatic mobility of adenocarcinoma cells, we examined cellular events of Colo201 cells when they acquire characteristics of adherent cells. We found that Colo201 cells were rapidly induced to adhere in response to protein kinase inhibitors, K252a and KT5720. The adhesion of Colo201 cells to ECM as well as cell spreading was mediated by integrin molecules, accompanied by activation of intracellular FAK and paxillin. These events were blocked by cyclosporin A and FK506, or by calmodulin inhibitors W7 and calmidazolium, indicating that calcineurin plays an important role in adhesion and spread of Colo201 cells.

\section{MATERIALS AND METHODS}

\section{Materials}

A human colon cancer cell line, Colo201, was obtained from the Japanese Cancer Research Resource Bank. The cells were grown in RPMI1640 medium supplemented with $10 \%$ fetal calf serum (FCS) (GIBCO-BRL Products, Gaithersburg, MD, USA) and antibiotics. $\left[{ }^{35} \mathrm{~S}\right]$ Methionine $(>800 \mathrm{Ci} / \mathrm{mmol})$ and carrier-free [32P]phosphoric acid were obtained from New England Nuclear (Boston, MA, USA). K252a, KT5720, KN62, staurosporin and calmidazolium chloride were purchased from CALBIOCHEM Co. (La Jolla, CA, USA). Herbimycin $\mathrm{A}$ and calphostine $\mathrm{C}$ were from Wako Pure Chemicals Co. (Osaka, Japan). Genistein, tautomycin, cycloheximide, actinomycin D, sodium vanadate and W7 were from Sigma Chemical Co. (St. Louis, MO, USA). FK506 and cyclosporin A were provided by Fujisawa Pharmaceutical Co., Ltd. (Osaka, Japan). A synthetic peptide GRGDSP was a product of Peptide Laboratories (Osaka, Japan). Anti-phosphotyrosine (4G10) and anti-integrin $\beta_{1}$ (mAb13) monoclonal antibodies were kind gifts from Dr. J. Fujisawa of our university. Anti-integrin $\alpha_{2}$ (P1E6) and $\alpha_{3}$ (P1B5) monoclonal antibodies were from CHEMICON International Inc. (Temecula, CA, USA). Anti-integrin $\beta_{1}$ monoclonal antibody (DF5) was from Affinity Research Products Ltd. (Exeter, UK). AntiFAK and anti-paxillin antibodies were from Transduction Research Laboratories (Lexington, KY, USA). Tissue culture dishes coated with collagen (type I), laminin, fibronectin or poly- $L$-lysine were products of Becton-Dickinson Co. (Lincoln Park, NJ, USA). All other reagents used in this study were of analytical grade.

\section{Morphological Studies and Inhibition Assays}

Colo201 cells were suspended in RPMI1640 medium containing 10\% FCS, and were aliquoted into collagen-, fibronectin-, laminin- or polylysine-coated tissue culture dishes. After a 1 h-incubation with $300 \mathrm{nM} \mathrm{K252a}$ or $500 \mathrm{nM}$ KT5720 at $37^{\circ} \mathrm{C}$, the cells were photographed using a phase contrast microscopy (Nikon Co., Tokyo, Japan). For inhibition assays, cells were suspended in RPMI1640 medium containing $1 \%$ bovine serum albumin and incubated on collagen-coated dishes, by adding each monoclonal antibody at a concentration of $5-10 \mu \mathrm{g} / \mathrm{ml}$, synthetic GRGDSP at a concentration of $1 \mathrm{mM}$, or FK506, cyclosporin A, W7, calmidazolium chloride and sodium vanadate at the indicated concentration at $37^{\circ} \mathrm{C}$ for $10 \mathrm{~min}$. Then $\mathrm{K} 252 \mathrm{a}$ at the final concentration of 300 $\mathrm{nM}$ was added, and the cells were incubated at $37^{\circ} \mathrm{C}$ for $1 \mathrm{~h}$. Non-adherent cells were separated from adherent-cells and cells counted.

\section{Immunoprecipitation and Immunoblotting}

Cells $\left(5 \times 10^{5}\right)$ were incubated without or with K252a, KT5720 or other reagents in RPMI1640 medium containing $1 \%$ bovine serum albumin at $37^{\circ} \mathrm{C}$ for $30 \mathrm{~min}$. The cells were then washed twice with phosphate buffered saline (PBS), and lysed in a solution containing $50 \mathrm{mM}$ Hepes- $\mathrm{NaOH}, \mathrm{pH} 7.4$, $150 \mathrm{mM} \mathrm{NaCl}, 0.5 \%$ sodium deoxycholate, $2 \mathrm{mM}$ EDTA, 1 $\mathrm{mM}$ sodium vanadate, $1 \%$ Nonidet $\mathrm{P}-40$ and $0.1 \mathrm{mM}$ phenylmethylsulfonylfluoride (PMSF) at $4^{\circ} \mathrm{C}$ for $20 \mathrm{~min}$ and cell lysates were centrifuged at $12,000 \times \mathrm{g}$ for $10 \mathrm{~min}$ to remove 
debris. The lysates were precleared with normal rabbit serum and then a Protein A Insoluble (Sigma Co., St. Louis, MO, USA) at $4^{\circ} \mathrm{C}$ for $30 \mathrm{~min}$ each. The lysates were incubated with anti-FAK, anti-paxillin or anti-integrin $\beta_{1}$ antibody, and then with anti-mouse IgG antibody coupled Sepharose beads (CHEMICON International Inc., Temecula, CA, USA) to collect antigen-antibody complexes. The beads were washed 5 times with $50 \mathrm{mM}$ Tris- $\mathrm{HCl}$ buffer, $\mathrm{pH} 7.4$, containing $0.5 \mathrm{M}$ $\mathrm{NaCl}, 1 \mathrm{mM}$ EDTA and $0.5 \%$ Triton X-100, and were boiled at $100^{\circ} \mathrm{C}$ for $1 \mathrm{~min}$ in a Laemmli's sample buffer (14). Proteins were separated on sodium dodecylsulfate-polyacrylamide gel electrophoresis (SDS-PAGE) and transferred onto a polyvinylidenedifluoride (PVDF) membrane (Bio-Rad Laboratories, Hercules, CA, USA). Immunoblotting was performed with monoclonal antibodies as primary antibodies, as described previously (36). Detection of immuno-complexes was made using enhanced chemiluminescence (Amersham, Buckinghamshire, UK). For metabolic labeling, the cells $\left(5 \times 10^{6}\right)$ were suspended in methionine-free RPMI1640 medium and in phosphate-free RPMI1640 medium, and then labelled with $\left[{ }^{35} \mathrm{~S}\right]$ methionine and $\left.{ }^{32} \mathrm{P}\right]$ phosphoric acid, as described (21). The cells were collected and washed twice with PBS. Immunoprecipitation was carried out with anti-integrin $\alpha_{2}$ or anti-integrin $\beta_{1}$ antibody, as described above. Labeled proteins were analyzed by SDS-PAGE. The gels were fixed, dried and exposed to $\mathrm{x}$-ray film at $-70^{\circ} \mathrm{C}$.

\section{Immunostaining of Colo201 Cells}

Plastic $35 \mathrm{~mm}$ dishes with inserted glass coverslips at the bottom were coated with polylysine $\left(5 \mu \mathrm{g} / \mathrm{ml}\right.$ in $\left.\mathrm{H}_{2} \mathrm{O}\right)$ for $2 \mathrm{~h}$. Colo201 cells were washed twice with serum-free RPMI1640 medium. Colo201 cells were incubated for $1 \mathrm{~h}$ on polylysine-coated dishes with $300 \mathrm{nM} \mathrm{K252a}$. To stain integrin molecules, the cells were washed twice with PBS containing $1 \mathrm{mM}$ $\mathrm{CaCl}_{2}$ and $0.5 \mathrm{mM} \mathrm{MgCl} 2$ [PBS(+)] and fixed in $4 \%$ paraformaldehyde in $\mathrm{PBS}(+)$ at room temperature for $20 \mathrm{~min}$. After blocking with $\mathrm{PBS}(+)$ containing $2 \% \mathrm{FCS}$, the cells were incubated with anti-integrin $\alpha_{2}$ or integrin $\beta_{1}$ in $\operatorname{PBS}(+)$ containing $2 \% \mathrm{FCS}$ at $37^{\circ} \mathrm{C}$ for $40 \mathrm{~min}$. The cells were then washed 5 times with $\operatorname{PBS}(+)$ and incubated with rhodamine-conjugated goat anti-mouse IgG antibody (Protos Immunoresearch, San Francisco, CA, USA) at 1/100 dilution at $37^{\circ} \mathrm{C}$ for $40 \mathrm{~min}$. After washing with $\mathrm{PBS}(+)$, the cells were visualized using an Olympus LSM-GB2000 confocal laser microscope (Olympus Co., Tokyo, Japan).

\section{RESULTS}

\section{Effect of Protein Kinase Inhibitors on Morphology of Colo201 Cells}

Colon adenocarcinoma Colo201 cells lose their cell-cell or cell-ECM adherence, and have a blood cell-like shape (32). To examine the properties of Colo201 cells regarding cell adhesion, the cells were exposed to various chemicals to acquire cell adhesion. Figure 1 shows the adhesion of Colo201 cells cultured on collagencoated plastic plates upon exposure to protein kinase inhibitors. Treatment of the cells with a general protein kinase inhibitor $\mathrm{K} 252 \mathrm{a}(100-300 \mathrm{nM})$ resulted in a marked appearance of adherent cells within $20 \mathrm{~min}$, followed by cell spreading. A protein kinase A inhibitor KT5720 (100-500 nM) also induced cell adhesion, but the rate of appearance was slower than that seen in the case of K252a. Another broad-spectrum protein kinase inhibitor staurosporin $(10 \mathrm{nM})$ led to cell adhesion, and membrane ruffling occurred (Figs. 1 and 2C). Among other inhibitors so far tested, a calmodulin-dependent protein kinase inhibitor KN62 $(10 \mu \mathrm{M})$ or tyrosine kinase inhibitors genistein $(50 \mu \mathrm{M})$ or herbimycin A $(10 \mu \mathrm{M})$ were without effect. An inhibitor of mitogen-activated protein kinase kinase PD-098059 (10 $\mu \mathrm{M})$, or protein kinase $\mathrm{C}$ inhibitors calphostine $\mathrm{C}$ (10 $\mu \mathrm{M})$ or H-7 $(100 \mu \mathrm{M})$ did not induce cell adhesion. To further determine if protein kinase $A$ is directly involved in cell adhesion, the cells were incubated with a cAMP analogue, Rp-cAMPS (50-200 $\mu \mathrm{M})$, but cell adhesion or spreading did not occur. The preincubation of Colo201 cells with dibutylic cAMP (0.5-2 mM) did not inhibit the cell adhesion induced by K252a. In phase-contrast microscopic observations, cells treated with $\mathrm{K} 252 \mathrm{a}$ for $1 \mathrm{~h}$ on collagen-, laminin-, and fibronectin-coated plates showed cell adhesion and spreading (Fgi. 2B, D, E). The cells on polylysine-coated plates also showed spreading with $\mathrm{K} 252 \mathrm{a}$ treatment (Fig. 2F), but no-adhesion occurred on non-coated plates (Fig. 2G). When the cells were incubated without $\mathrm{K} 252 \mathrm{a}$ on any protein-coated plates, the cells re-

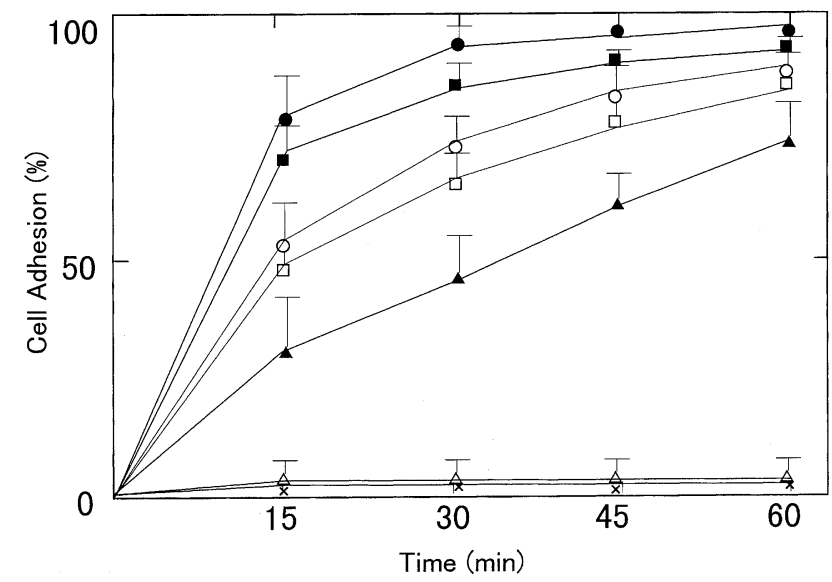

Fig. 1. Effect of protein kinase inhibitors on cell adhesion of Colo201 cells. The cells $\left(1 \times 10^{6}\right)$ were suspended in RPMI1640 medium containing $10 \% \mathrm{FCS}$, and incubated at $37^{\circ} \mathrm{C}$ for $1 \mathrm{~h}$ without $(\times)$, or with $100 \mathrm{nM} \mathrm{K252a}(\bigcirc), 300 \mathrm{nM} \mathrm{K252a}()_{)}, 100 \mathrm{nM} \mathrm{KT} 5720$


$(\triangle)$. At the indicated time, the floating cells were withdrawn and counted. Data are the mean \pm S.E. of triplicate experiments. 

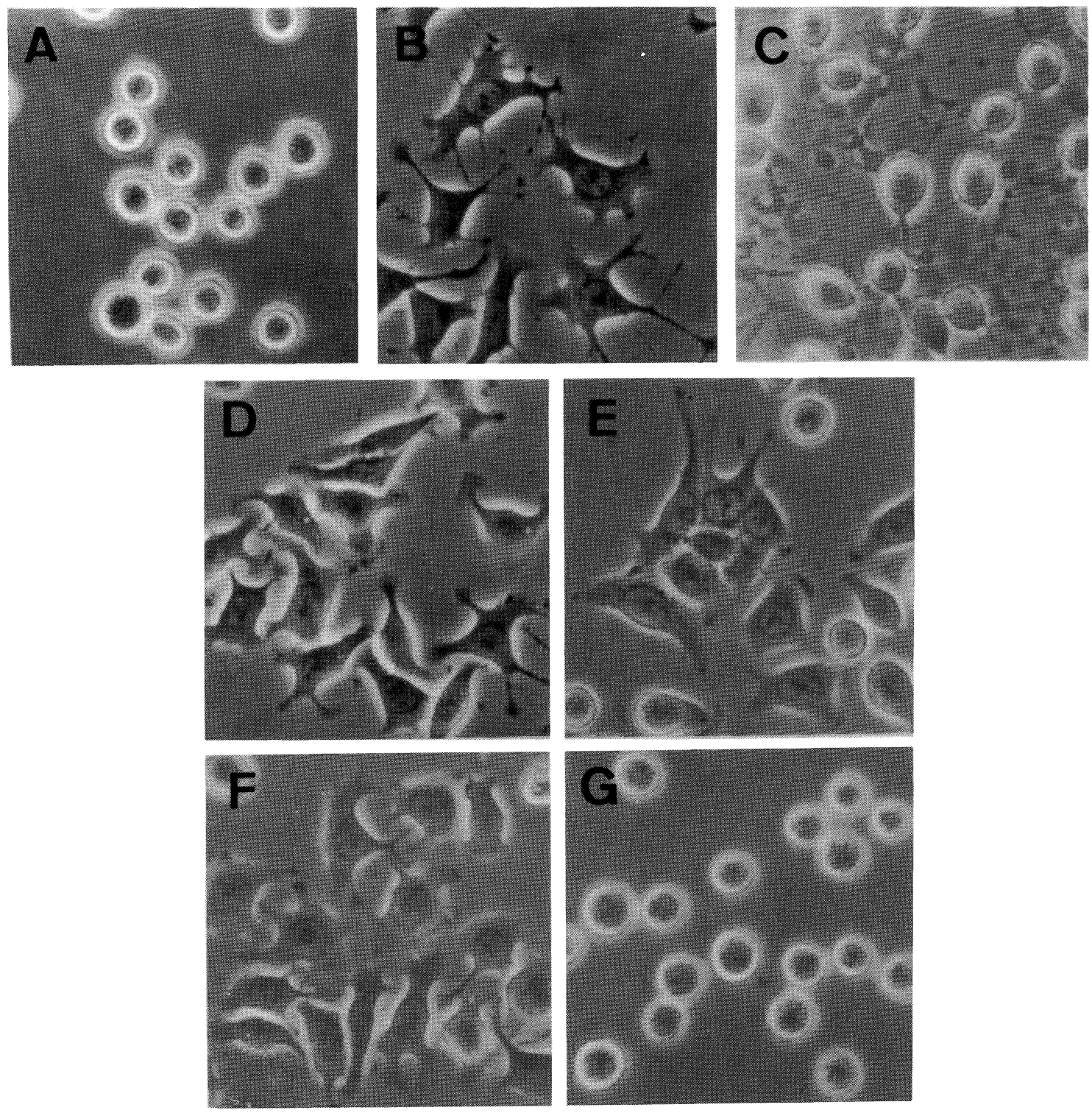

Fig. 2. Morphology of Colo201 cells. The cells were seeded on collagen-(A-C), laminin-(D), fibronectin-(E) and polylysine-(F) and non-(G) coated plates. Cell morphologies were photographed at $\times 200$ after a 1 h-incubation without (A) or with $300 \mathrm{nM} \mathrm{K252a} \mathrm{(B,} \mathrm{D-G)} \mathrm{or} 10 \mathrm{nM}$ staurosporin (C) at $37^{\circ} \mathrm{C}$.

mained round (Fig. 2A). Cycloheximide $(5 \mu \mathrm{g} / \mathrm{ml})$ or actinomycin D $(2 \mu \mathrm{g} / \mathrm{ml})$ did not affect either cell adhesion or spreading, indicating that these events were independent of protein and RNA syntheses. We then examined the effects of divalent cations on cell adhesion. Cells incubated in PBS with $\mathrm{Mg}^{2+}(5 \mathrm{mM}), \mathrm{Ca}^{2+}(1$ $\mathrm{mM})$ or $\mathrm{Mn}^{2+}(0.2 \mathrm{mM})$ were induced to the adhesion and spread with K252a, but no adhesion occurred without divalent cations (Fig. 3). Therefore, cell-surface molecule integrins may be involved in the adhesion of Colo201 cells by these treatments.

\section{Involvement of Integrin Molecules in K252a-induced Cellular Adhesion and Spreading}

To determine if integrins are involved in K252a-induced cell adhesion and spreading of Colo201 cells, RGD peptide (GRGDSP) was added to the medium, and Colo201 cells on collagen-coated plates were incubated with K252a. RGD peptide (1 mM) did not affect adhesion and spreading, but did inhibit it on fibronectin-coated plates (Fig. 4). Next we examined the effects of monoclonal antibodies for integrins on cell adhesion, using collagen-coated plates. Of the tested antibodies, anti-integrin $\beta_{1}$ and $\alpha_{2}$ antibodies inhibited the 


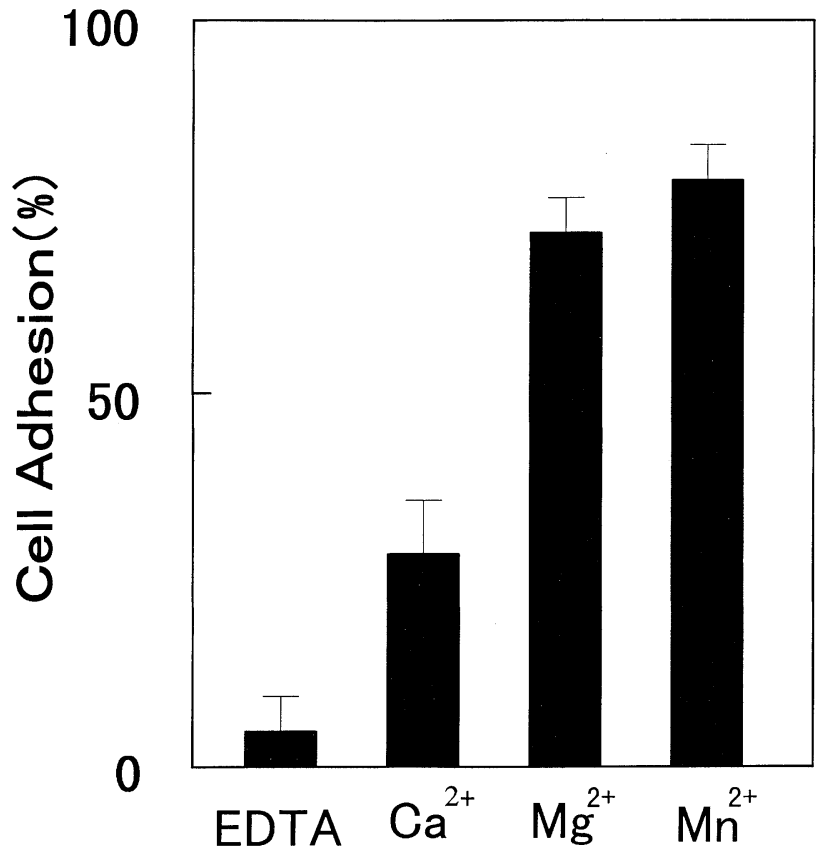

Fig. 3. Effect of divalent cation on K252a-induced cell adhesion of Colo201 cells. The cells were suspended in PBS with 1 mM EDTA, 1 $\mathrm{mM} \mathrm{Ca}^{2+}, 5 \mathrm{mM} \mathrm{Mg}^{2+}$ or $0.2 \mathrm{mM} \mathrm{Mn}^{2+}$ and incubated with $300 \mathrm{nM}$ K252a on collagen-coated plates at $37^{\circ} \mathrm{C}$ for $1 \mathrm{~h}$. Non-adherent cells were collected and counted. Data are the means \pm S.E. of triplicate experiments.

cell adhesion in a dose-dependent manner, while antiphosphotyrosine antibody (4G10) as control or anti-integrin $\alpha_{3}$ antibody did not inhibit the adhesion, indicating that the K252a-induced cell spreading was mediated by integrin $\alpha_{2}$ and $\beta_{1}$ (Fig. 4). Potency of the inhibition by anti-integrin $\beta_{1}$ was more than that by anti-integrin $\alpha_{2}$. Indirect immunofluorescence microscopic observations revealed that integrin $\beta_{1}$ as well as integrin $\alpha_{2}$ were localized at focal adhesion sites in K252a-treated cells while diffuse locations of both molecules were observed in control cells (Fig. 5). These results indicated that the K252a-induced cell spreading of Colo201 cells was accompanied by integrin activation. Immunoprecipitation with anti-integrin $\beta_{1}$ was then carried out with lysates from the cells metabolically labeled with $\left[{ }^{35} \mathrm{~S}\right]$ methionine, and immunoprecipitates were analyzed by SDS-PAGE. Integrin $\beta_{1}$ complexed with the corresponding $\alpha$ chains was found in K252a-treated cells, and these events were similar to those in control cells (data not shown). To further examine phosphorylation of the integrin $\beta_{1}$ in K252a-induced adherent Colo201 cells, the cells were incubated with [32 P] phosphoric acid, and then treated with $\mathrm{K} 252 \mathrm{a}$, followed by immunoprecipitation with anti-integrin $\beta_{1}$. Analysis by SDS-PAGE showed that phosphorylated-integrin $\beta_{1}$ in Colo201 cells did not change with K252a treatment.



Fig. 4. Effects of monoclonal antibodies for integrin $\alpha_{3}, \alpha_{2}$ and $\beta_{1}$, and RGD peptide on K252a-induced cell adhesion of Colo201 cells. The cells were suspended in RPMI1640 medium containing 1\% bovine serum albumin, seeded on collagen-coated plates, and then incubated with $300 \mathrm{nM} \mathrm{K252a}$ plus anti-phosphotyrosine $4 \mathrm{G} 10(10 \mu \mathrm{g}$ $/ \mathrm{ml}$ ), anti-integrin $\beta_{1}$ (mAb13), anti-integrin $\alpha_{2}$ (P1E6), anti-integrin $\alpha_{3}$ (P1B5) or $1 \mathrm{mM}$ GRGDSP for $1 \mathrm{~h}$. The cells on fibronectincoated plates were also incubated with $300 \mathrm{nM} \mathrm{K252 \textrm {a }}$ in the presence or absence of $1 \mathrm{mM}$ GRGDSP for $1 \mathrm{~h}$ (open column). Non-adherent cells were collected and counted. Monoclonal antibodies for integrins used were $5 \mu \mathrm{g} / \mathrm{ml}$ (left column) and $10 \mu \mathrm{g} / \mathrm{ml}$ (right column). Data are the means \pm S.E. of triplicate experiments.

The profile in which integrins were immunoprecipitated with anti-integrin $\alpha_{2}$ was similar between K252a and control cells (data not shown), indicating that complexes of integrin $\alpha_{2}$ and $\beta_{1}$ remain unchanged during treatment with K252a.

\section{Effect of Protein Phosphatase Inhibitors on K252a- induced Adhesion of Colo201 Cells}

We next examined the effects of protein phosphatase inhibitors on the K252a-induced adhesion and spreading. As shown in Fig. 6, inhibitors for protein phosphatase calcineurin, FK506 and cyclosporin A suppressed the adhesion and spreading of K252a-treated cells in a dose-dependent manner. Since FK506 and cyclosporin bind to FKBP and cyclophilin A, respectively, inhibit calmodulin-dependent phosphatase calcineurin (18), the effects of calmodulin inhibitors on the adhesion were also examined. By increasing concentrations of calmodulin inhibitors, W7 as well as calmidazolium, K252a-induced cell adhesion was inhibited, in a dosedependent manner. On the other hand, okadaic acid (50-200 nM) or tautomycin (1-10 nM), inhibitors of serine/threonine phosphatase 1 and $2 \mathrm{~A}$, or sodium vanadate (0.5-2 mM), an inhibitor of serine/threonine phosphatase $1,2 \mathrm{~A}$ and $2 \mathrm{C}$ and of most tyrosine phosphatases, did not suppress adhesion and spreading of K252a-treated cells. These results indicate that the blocking of the calcium-dependent calcineurin signal pathway inhibits the K252a-induced adhesion and 

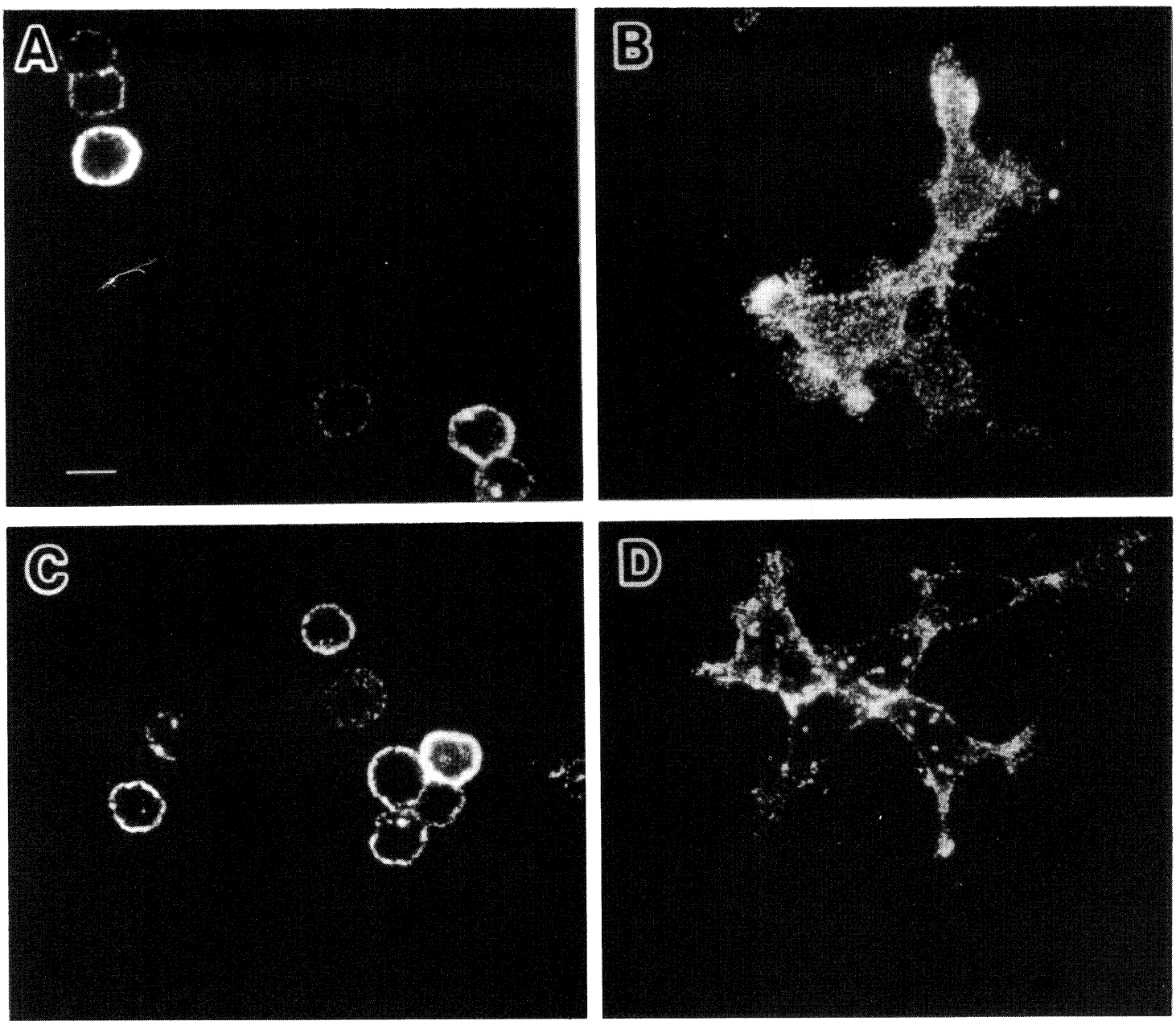

Fig. 5. Effect of K252a on the distribution of integrins $\alpha_{2}$ and $\beta_{1}$ of Colo201 cells. Conditions of incubation of the cells were similar to those described in the legend of Fig. 4. Cells were fixed and stained with antibodies for integrin $\alpha_{2}(\mathrm{~A}, \mathrm{~B})$ and $\beta_{1}(\mathrm{C}, \mathrm{D})$. Whereas the integrins appeared to be present diffusely in control cells $(\mathrm{A}, \mathrm{C})$, they are localized to focal adhesions underlying K252a-treated cells $(\mathrm{B}, \mathrm{D})$. Bars $=20 \mu \mathrm{m}$.

spreading of Colo201 cells.

\section{Association of tyrosine phosphorylation of intracellu-} lar protein in K252a- and KT5720-treated Colo201 cells We finally examined tyrosine phosphorylation in K252a- and KT5720-treated Colo201 cells. As shown in Fig. 7A, phosphoproteins corresponding to molecular masses of about $70 \mathrm{kDa}, 90 \mathrm{kDa}, 120 \mathrm{kDa}, 160 \mathrm{kDa}$ and $220 \mathrm{kDa}$ increased by K252a- and KT5720-treatments. Marked elevations of phosphoproteins with $70 \mathrm{kDa}$ and $120 \mathrm{kDa}$ occurred in cells treated with K252a for 30 min. To identify the phosphoproteins, immunoprecipitation was performed with anti-FAK and anti-paxillin antibodies, and immunoblotting was performed with anti-phosphotyrosine antibody after analysis by SDSPAGE. Phosphorylations of FAK and paxillin were clearly increased by K252a or KT5720 treatment (Fig. $7 \mathrm{~B}, \mathrm{C}$ ), indicating that major phosphoproteins induced by drugs were identified with FAK and paxillin. When cells were incubated with K252a (300 nM) and FK506 $(20 \mu \mathrm{M})$ in combination, major phosphotyrosine proteins including FAK and paxillin were diminished (Fig. 7D). FK506 also blocked tyrosine phosphorylation of KT5720-treated cells. Cyclosporin A $(10 \mu \mathrm{M})$ also blocked the phosphorylation of the proteins (data not shown). Thus, adhesion and spread of Colo201 cells by K252a- and FT5720-treatments were accompanied by increases in tyrosine phosphorylation of FAK and paxillin, and suppression of cell adhesion by calicineurin inhibitors was accompanied by abolition of tyrosine phosphorylation.

\section{DISCUSSION}

This study demonstrated that the rapid adhesion and spread of non-adherent colon carcinoma Colo201 cells 


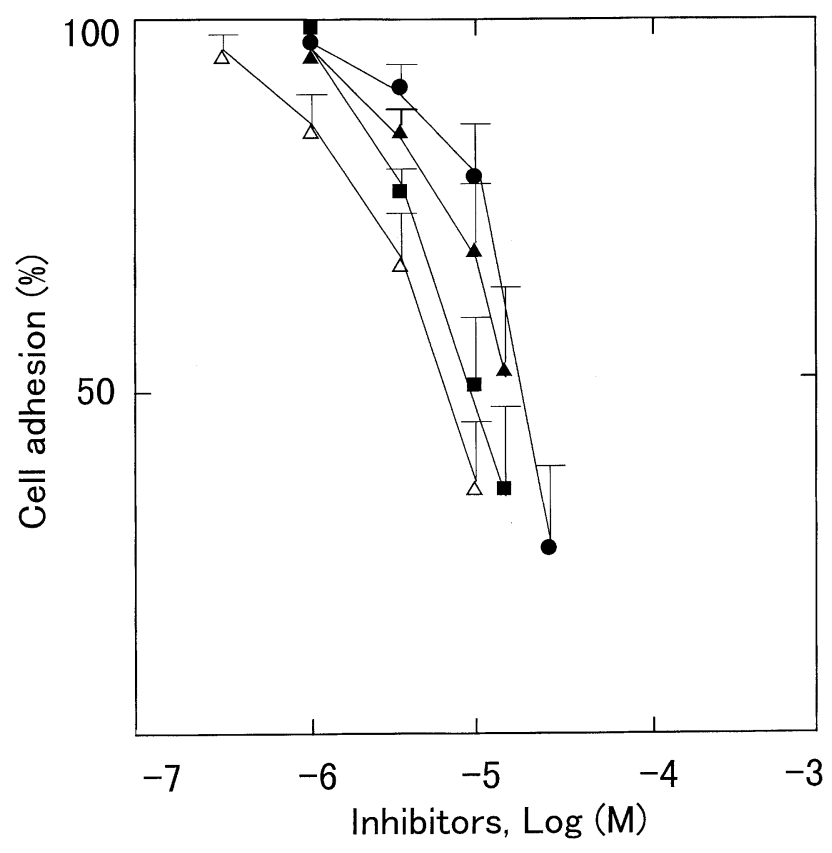

Fig. 6. Effect of FK506, cyclosporin A, W7 and calmidazolium on K252a-induced Colo201 cell adhesion. Incubation conditions of cells were similar to those described in the legend of Fig. 5, except that the indicated concentrations of FK $506(\square)$, cyclosporin A $(\boldsymbol{\Delta})$, W7

(O) and calmidazolium chloride $(\triangle)$ were added. Non-adherent cells were separated from adherent cells and counted. Data are the means \pm S.E. of triplicate experiments.

effected by treatment with protein kinase inhibitors K252a and KT5720, and that this spreading was markedly suppressed by combined treatment with cyclosporin A and FK506, inhibitors of protein phosphatase 2B, calcineurin. Staurosporin and K252a are general kinase inhibitors, and inhibit protein kinase $\mathrm{A}$, protein kinase $\mathrm{C}$ and calmodulin-dependent protein kinase. The possibility of involvement of protein kinase $\mathrm{C}$ or calmodulin-dependent protein kinase in the cell spreading was ruled out by observations that these kinase inhibitors, calphostine $\mathrm{C}, \mathrm{H} 7$ or KN62 did not induce adhesion or spreading. On the other hand, a protein kinase A inhibitor KT5720 did induce cell spreading, suggesting that elevation of protein kinase A in Colo201 cells may be related to the loss of the potential to adhere. These findings are consistent with privious observations that activation of protein kinase A causes a variety of cells to become partially round and to develop arborized cell processes $(5,35)$. When we examined the inhibitory effect of cAMP on the K252a-induced adhesion of Colo201 cells, even in the presence of dibutylic cAMP $(0.5-2 \mathrm{mM})$ the cells continued to spread out. Furthermore, the addition of a cAMP analogue Rp-cAMPS (50-200 $\mu \mathrm{M})$ did not induce adhesion of Colo201 cells. These results suggest that protein kinase $\mathrm{A}$ is not direct- ly or solely related to the adhesion of Colo201 cells. We examined the effect of K252a of KT5720 on cell adhesion and spreading of other non-adherent cells. Of cell lines tested, human Jurkat $\mathrm{T}$ leukemia cells and mouse erythroleukemia Friend cells showed results similar to those seen in the case of Colo201 cells (Mohri and Taketani, unpublished observations), indicating that the appearance of adherent cells by the treatment is not specific for Colo201 cells. Based on a finding that the effect of K252a and KT5720 on cell spreading was irreversible, these inhibitors activate metastasis-suppressor molecules and are therefore candidates for chronic antimetastatic treatment of cancer.

The adhesion of Colo201 cells induced by K252a could be accompanied by activation of integrin molecules since the adhesion is dependent on divalent cations such as $\mathrm{Mg}^{2+}, \mathrm{Mn}^{2+}$ and $\mathrm{Ca}^{2+}$. In addition, the binding of the cells to collagen-coated plates was inhibited by antibodies for integrin $\beta_{1}$ or $\alpha_{2}$, and that to fibronectin-coated plates was inhibited by RGD peptide (Fig. 4). These findings differ from the observations of Yoshimura et al. (38) that integrin $\alpha_{3} \beta_{1}$ but not $\alpha_{2} \beta_{1}$ mediated staurosporin-induced spreading of Colo201 cells. Recently we reported that the expression of integrin $\alpha_{3}$ in Colo201 cells used in our study is much lower than those of other integrin molecules (20). The present data showed that anti-integrin $\alpha_{3}$ antibody did not inhibit the binding or spreading of the cells to collagen-coated plates, indicating that integrin $\alpha_{3}$ in the cells does not contribute to cell adhesion. Furthermore, our data revealed that staurosporin induced membrane ruffling in Colo201 cells rather than cell spreading (Fig. 2C). Based on observations that a rasrelated GTP binding protein rac regulates membrane ruffling in Swiss 3 T3 cells (28), it is thought that the inhibition of protein kinases by staurosporin in Colo201 cells is being activated by the intracellular signal transduction pathway, such as those acting through rac.

It was reported that the activation of protein kinase $\mathrm{C}$ by TPA induced the enhancement of integrin-dependent cell adhesion, the formation of stress fibers, as well as focal contact in colon carcinoma cells $(2,13,29)$, while TPA had no apparent effect on adhesion of Colo201 cells. TPA also enhances $\alpha_{5} \beta_{1}$ mediated adhesion of Chinese hamster ovary cells (37) and human leukemic NB4 cells (19). Although microscopic observations showed that integrins $\alpha_{2}$ and $\beta_{1}$ in K252a treated cells were localized at focal adhesion contacts with concomitant formation of actin stress fibers, the increase in adhesion does not result from a modulation of the expression of integrin molecules at the membrane surface or from change in phosphorylation of integrin $\beta_{1}$. Since K252a exhibits high affinity for protein kinase $C$, the cell adhesion and spreading by K252a is independent of activation of protein kinase $C$, which is 
A

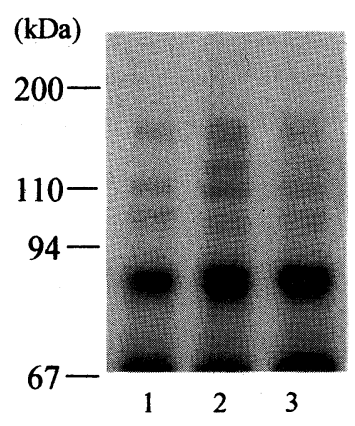

B



$\mathrm{C}$

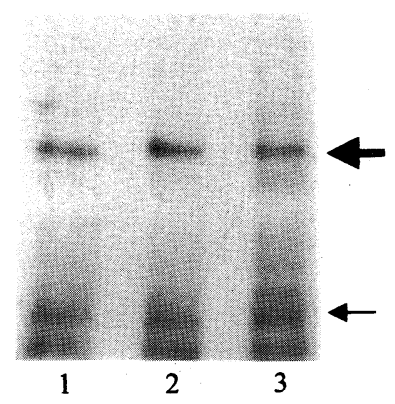

$\mathrm{D}$



Fig. 7. Changes in tyrosine phosphorylation of cellular proteins in K252a-treated Colo201 cells. (A) Proteins from cells treated with $300 \mathrm{nM}$ K252a or $500 \mathrm{nM} \mathrm{KT5720} \mathrm{were} \mathrm{subjected} \mathrm{to} \mathrm{SDS-PAGE} \mathrm{on} \mathrm{a} 7.5 \%$ gel, and transferred onto a PVDF membrane. Immunoblotting was performed with anti-phosphotyrosine antibody (4G10), as the primary antibody. (B, C) Immunoprecipitation was carried out with anti-FAK and anti-paxillin antibodies, in combination. After immunoprecipitates had been analyzed by SDS-PAGE on a $6 \%$ gel and electroblotted, immunoblotting was performed using anti-FAK and anti-paxillin antibodies (B) or with 4G10 (C). Samples were from cells incubated without (lane 1), or with $300 \mathrm{nM} \mathrm{K252a}$ (lane 2) or $500 \mathrm{nM} \mathrm{KT} 5720$ (lane 3) at $37^{\circ} \mathrm{C}$ for $30 \mathrm{~min}$. (D) The cells were also treated without (lane 1) or with $300 \mathrm{nM}$ K252a (lane 2), K252a plus $20 \mu \mathrm{M}$ FK506 (lane 3), FK506 (lane 4), $500 \mathrm{nM} \mathrm{KT} 5720$ plus $20 \mu \mathrm{M}$ FK506 (lane 5) or $500 \mathrm{nM} \mathrm{KT5720} \mathrm{(lane} \mathrm{6)} \mathrm{at} 37^{\circ} \mathrm{C}$ for 30 min. The cellular proteins were analyzed by SDS-PAGE, and transferred to the membrane, followed by immunoblots with 4G10, as above. Thick and thin arrows show positions of FAK and paxillin, respectively.

similar to findings that lysophosphatidic acid induced assembly of cytoskeleton and formation of focal adhesion in mouse $3 \mathrm{~T} 3$ cells by a pathway largely independent of protein kinase $\mathrm{C}$ activation (33). It is also known that rho protein regulates activation of integrins, followed by formation of actin stress fibers, in a variety of cell lines $(23,27)$. We did not examine involvement of rho and rho-related proteins in cell spreading of K252atreated Colo201 cells, but a rapid response of Colo201 cells to kinase inhibitors should allow for a biochemical analysis of mechanisms of focal adhesion and stress fiber formation and also provide insight into the molecular functions of rho.

Tyrosine phosphorylation of FAK and paxillin is elevated following activation of integrins $(1,12,25)$, and in its response to mitogens such as lysophosphatidic acid, platelet-derived growth factor and sphingosylphosphatidylcholine, is critically dependent on the in- tegrity of the actin cytoskeleton $(25,33,34)$. Tyrosine phosphorylation of FAK and paxillin is co-ordinately regulated in intact cells $(26,30)$. The present results show that the dramatic change in cell shape in response to K252a and KT5720 was accompanied by increases in tyrosine phosphorylation of FAK and paxillin. Furthermore, FK506 and cyclosporin A diminished phosphorylation of FAK and paxillin with concomitant suppression of cell adhesion. In addition to FAK and paxillin, we found that several phosphoproteins with molecular mass of $220 \mathrm{kDa}, 160 \mathrm{kDa}$ and 90 $\mathrm{kDa}$ were enhanced in response to K252a. During cell spreading, additional phosphoproteins such as talin, p130 Cas, tensin and Src are activated and some aare bound to FAK (3). Since the phosphorylation of tensin and $\mathrm{Src}$ is observed in staurosporin-treated Colo201 cells and the molecular mass of tensin is $220 \mathrm{kDa}(38)$, the $220 \mathrm{kDa}$-phosphoprotein enhanced by K252a corre- 
sponds to tensin. Thus, a complex network of structural and signal transduction proteins is formed in K252atreated Colo201 cells.

Biochemical investigations suggest that the $\mathrm{Ca}^{2+}$ - and calmodulin-dependent calcineurin is a common "downstream" biological target of cyclosporin A and FK506. As these agents exhibit specificity for activation pathway that induces an increase in intracellular $\mathrm{Ca}^{2+}$, such as those mediated by the $\mathrm{T}$ cell receptors and $\mathrm{IgE}$ receptor $(9,31)$, calcineurin may be involved in regulating the phosphorylation state of a downstream component of these signaling pathways. The cellular specificity of the action of FK506 and cyclosporin A may be related to selective interactions with specific isoforms of calcineurin or due to the existence of cell-specific calcineurin substrates. The tyrosine phosphorylation in K252atreated or control cells was deeply diminished by FK506 and cyclosporin, suggesting that tyrosine phosphorylation involved in cell adhesion of Colo201 cells is a possible downstream action of calcineurin. A recent study showed that paxillin in rat liver epithelial cells is phosphorylated and is associated with calcium-dependent tyrosine kinase (16), thus supporting the notion of 'inside-out' signaling that calcineurin directly or indirectly dominates tyrosine phosphorylation of signal transduction proteins and indirectly controls integrins.

Other investigators $(8,15)$ reported that $\mathrm{Ca}^{2+}$ and calcineurin regulate motility of neutrophils on vitronectin through an integrin molecule. Interaction of integrin $\alpha_{5} \beta_{1}$ with fibronectin in vitro was seen to be controlled by calcineurin (24). The present study shows that inhibition of calcineurin by FK506 overcomes the K252a-induced cell adhesion of Colo201 cells. Taken together, the calcineurin-dependent regulation occurs under physiological conditions. FK506 and cyclosporin $A$ induced other adherent colon cancer cells including Widr and DLD-1 cells to detach from culture plates (Taketani and Suzuki, unpublished observations). Therefore, it is possible that the dysfunction of calcium-dependent calcineurin may be related to invasion and metastasis of human colon cancer cells. Alternatively, immunosuppressants FK506 and cyclosporin A seem to trigger inactivation of integrin-dependent adhesion and detachment of carcinoma cells from ECM although we cannot rule out the possibility that the effects of these inhibitors on cell-ECM interactions are indirect and not due to direct inhibition of calcineurin function. Further studies are needed to clarify the regulatory mechanisms governing calcineurin-dependent cell adhesion and metastasis, in vivo and in vitro.

Acknowledgments. We thank Dr. J. Fujisawa for kind gifts of $4 \mathrm{G} 10$ and mAb13, Drs. T. Okumura and S. Sogo for valuable suggestions, K. Kobayashi for help with the confocal microscopy, and Y. Masu and M. Ohara for comments. This study was supported in part by a grant from the Ministry of Education, Science, Sports and Culture of Japan and by a research grant from Sumitomo Chemical Co.

\section{REFERENCES}

1. Burridge, K., Turner, C.E., and Romer, L.H. 1992. Tyrosine phosphorylation of paxillin and p125FAK accompanies cell adhesion to extracellular matrix: a role in cytoskeletal assembly. J. Cell Biol., 119: 893-903.

2. Chiang, H.-S., Peng, H.-C., and Huang, T.-F. 1994. Characterization of integrin expression and regulation on SW-480 human colon adenocarcinoma cells and effect of rhodostomin on basal and upregulated tumor cell adhesion. Biochim. Biophys. Acta, 1224: 506-516.

3. Clark, E.A. and Brugge, J.S. 1995 . Integrins and signal transduction pathways: The road taken. Science, 268: 233-239.

4. Defilippi, P., Retta, S.F., Olivo, C., Palmieri, M., Venturino, M., Silengo, L., and TARone, G. 1995. p125 tyrosine phosphorylation and focal adhesion assembly: Studies with phosphotyrosine phosphatase inhibitors. Exp. Cell Res., 221: 141-152.

5. Glass II, W.F. and KreisBerg, J.I. 1993. Regulation of integrin-mediated adhesion at focal contacts by cyclic AMP. J. Cell Physiol., 157: 296-306.

6. Golden, A., Brugge, J.S., and Shattil, S.J. 1990. Role of platelet membrane glycoprotein IIb-IIIa in agonist-induced tyrosine phosphorylation of platelet proteins. J. Cell Biol., 111: 3117-3127.

7. Guan, J.-L., Trevithick, J.E., and Hynes, R.O. 1991. Fibronectin/integrin interaction induces tyrosine phosphorylation of a 120-kDa protein. Cell Regul., 2: 951-964.

8. Hendey, B., KleE, C.B., and Maxfield, F.R. 1992. Inhibition of neutrophil chemokinesis on vitronectin by inhibitors of calcineurin. Science, 258: 296-299.

9. Hultsch, T., Albers, M.W., Schreiber, S.L., and Hohman, R.J. 1991. Immunophilin ligands demonstrate common feature of a signal transduction leading to exocytosis or transcription. Proc. Natl. Acad. Sci. (USA), 88: 6229-6233.

10. Hynes, R.O. and Lander, A.D. 1992. Contact and adhesive specificities in the associations, migrations and targeting of cells and axons. Cell, 68: 303-322.

11. HyNES, R.O. 1992. Integrins: versatility, modulation and signalling in cell adhesion. Cell, 69: 11-25.

12. Kornberg, L., Earp, H.S., Parsons, J.T., Schaller, M., and Juliano, R.L. 1992. Cell adhesion or integrin clustering increases phosphorylation of a focal adhesion-associated tyrosine kinase. J. Biol. Chem., 267: 23439-23442.

13. Kuo, M.-L., Huang, T.-S., and Lin, J.-K. 1995. Preferential requirement for protein tyrosine phosphatase activity in the 12$O$-tetradecanoyl-13-acetate-induced differentiation of human colon cancer cells. Biochem. Pharmacol., 50: 1217-1222.

14. LAEMMLI, U.K. 1970. Cleavage of structural proteins during the assembly of the head of bacteriophage T4. Nature, 227: 680685.

15. Lawson, M.A. and Maxfield, F.R. 1995. $\mathrm{Ca}^{2+}$ - and calmodulin-dependent recycling of an integrin to the front of migration neutrophils. Nature, 377: 75-79.

16. LI, X. and EARP, H.S. 1997. Paxillin is tyrosine-phosphorylated by and preferentially associates with the calcium-dependent tyrosine kinase in rat liver epithelial cells. J. Biol. Chem., 272: 14341-14348.

17. Liotta, L.A., Steeg, P.S., and Stetler-Stevenson, W.G. 
1991. Cancer metastasis and angiogenesis: An imbalance of positive and negative regulation. Cell, 64: 327-336.

18. Liu, J., Farmer, JR. J.D., Lane, W.S., Friedman, J., Weissman, I., and SchreIBer, S.L. 1991. Calcineurin is a common target of cyclophilin-cyclosporin A and FKBP-FK506 complexes. Cell, 66: 807-815.

19. Martin-Thouvenin, V., Gendron, M.C., and Hogervorst, F. 1992. Phorbol ester-induced promyelocytic leukemia cell adhesion to marrow stromal cells involves fibronectin specific $\alpha_{5} \beta_{1}$ integrin receptors. J. Cell Physiol., 153: 95-102.

20. Nakagawa, M., Sogo, S., Hioki, K., Tokunaga, R., and TAKETANI, S. 1998. Acquisition of cell adhesion and induction of focal adhesion kinase of human colon cancer Colo201 cells by retinoic acid-induced differentiation. Differentiation, 62: 249-257.

21. Obata, S., Sago, H., Mori, N., Rochelle, J.M., Seldin, M.F., Davidson, M., St John, T., TaKetani, S., and Suzuki, T.S. 1995. Protocadherin Pcdh2 shows properties similar to, but distinct from, those of classical cadherins. J. Cell Sci., 108: 3765-3773.

22. O'Toole, T.E., Mandelman, D., Forsyth, J., Shattil, S.J., Plow, E.F., and GinsberG, M.H. 1991. Modulation of the affinity of integrin $\alpha_{\mathrm{IIb}} \beta_{3}$ (GPIIb-IIIa) by the cytoplasmic domain of $\alpha_{\mathrm{IIb}}$. Science, 254: 845-847.

23. Paterson, H.F., Self, A.J., Garrett, M.D., Just, I., Aktories, K., and Hall, A. 1990. Microinjection of recombinant p21rho induces rapid changes in cell morphology. J. Cell Biol., 111: 1001-1007.

24. Pomies, P., Frachet, P., and Block, M.R. 1995. Control of the $\alpha_{5} \beta_{1}$ integrin/fibronectin interaction in vitro by the serine/threonine protein phosphatase calcineurin. Biochemistry, 34: 5104-5112.

25. Rankin, S. and Rozengurt, E. 1994. Platelet-derived growth factor modulation of focal adhesion kinase (p125 $\left.5^{\mathrm{FAK}}\right)$ and paxillin tyrosine phosphorylation in Swiss 3T3 cells. Bell-shaped dose response and cross-talk with bombesin. J. Biol. Chem., 269: 704-710.

26. Retta, S.F., Barry, S.T., Critchley, D.R., Defilippi, P., SiEngo, L., and TARone, G. 1996. Focal adhesion and stress fiber formation is regulated by tyrosine phosphatase activity. Exp. Cell Res., 299: 307-317.

27. RIDLEY, A.J. and HALL, A. 1992. The small GTP-binding protein rho regulates the assembly of the focal adhesions and actin stress fibers in response to growth factors. Cell, 70: 389-399.

28. Ridley, A.J., Paterson, H.F., Johnstone, C.L., Diekman, D., and HALL, A. 1995. The small GTP-binding protein rac regulates growth factor-induced membrane ruffling. Cell, $\mathbf{7 0}$ : 401-410.
29. SaKamoto, M., Ino, Y., Ochial, A., Kanai, Y., Akimoto, S., and HiRoHASHI, S. 1996. Formation of focal adhesion and spreading of polarized human colon cancer cells in association with tyrosine phosphorylation of paxillin in response to phorbol ester. Labo. Invest., 74: 199-208.

30. Schaller, M.D., Otey, C.A., Hilderbrand, J.D., and PARSONS, J.T. 1995. Focal adhesion kinase and paxillin bind to peptides mimicking $\beta$-integrin cytoplasmic domains. J. Cell Biol., 130: 1181-1187.

31. SCHREIBER, S.L. 1991. Chemistry and biology of the immunophilins and their immunosuppressive ligands. Science, 251: 283287.

32. Semple, T.U., QuinN, L.A., Woods, L.K., and Moore, G.E. 1978. Tumor and lymphoid cell lines from a patient with carcinoma of the colon for a cytotoxicity model. Cancer Res., 38: 1345-1355.

33. Seufferien, T. and Rozengurt, E. 1994. Lysophosphatidic acid stimulates tyrosine phosphorylation of focal adhesion kinase, paxillin and p130. Signaling pathway and cross-talk with platelet-derived growth factor. J. Biol. Chem., 269: 9345-9351.

34. Seufferien, T. and Rozengurt, E. 1995. Sphingosylphosphorylcholine rapidly induces tyrosine phosphorylation of $\mathrm{p} 124^{\mathrm{FAK}}$ and paxillin, rearrangement of the actin cytoskeleton and focal contact assembly. Requirement of p21rho in the signaling pathway. J. Biol. Chem., 270: 24343-24351.

35. Spruill, W.A., White, M.G., Steiner, A.L., Tres, L.L., and Kierszennaum, A.L. 1981. Temporal sequence of cell shape changes in cultured rat sertoli cells after experimental elevation of intracellular cAMP. Exp. Cell Res., 91: 449-453.

36. Taketani, S., Kohno, H., Okuda, M., Furukawa, T., and TOKUNAGA, R. 1994. Induction of peripheral benzodiazepine receptors during differentiation of mouse erythroleukemia cells. J. Biol. Chem., 269: 7527-7531.

37. VUORI, K. and Ruoslahti, E. 1993. Activation of protein kinase c precedes $\alpha_{5} \beta_{1}$ integrin-mediated cell spreading on fibronectin. J. Biol. Chem., 268: 21459-21462.

38. Yoshimura, M., Nishikawa, A., Nishiura, T., Ihara, Y., Kanayama, M., Matsuzawa, Y., and Taniguchi, N. 1995. Cell spreading in Colo201 cells by staurosporin is $\alpha_{3} \beta_{1}$ integrin-mediated with tyrosine phosphorylation of src and tensin. J. Biol. Chem., 270: 2298-2304.

(Received for publication, June 26, 1998

and in revised form, July 27, 1998) 